\title{
ФУНКЦОНАЛЬНО-СТРУКТУРНА МОДЕЛЬ ТОВАРУ ЯК ОСНОВА ДЛЯ СТРЕС-ТЕСТУВАННЯ МАРКЕТИНГОВОЇ БІЗНЕС-МОДЕЛІ КОМПАНІї
}

\section{FUNCTIONAL-STRUCTURAL MODEL OF THE GOODS AS A BASIS FOR STRESS-TESTING OF A MARKETING BUSINESS MODEL OF A COMPANY}

Стаття присвячена аналізу внутрішніх зв'язків між маркетинговими моделями товару та моделями аналізу конкурентоспроможності бізнесу, зокрема моделлю 5 сил М. Портера та бізнес-моделями. Наведено класифікаџію маркетингових моделей товару із зазначенням ключових складових та загального спрямування аналізу товару для кожної моделі. Розроблено структурно-функиіональну модель, яка, на відміну від існуючих, зосереджується не на иінності, яку надає товар споживачеві, а на його технологічно-функиіональній базі. Модель містить три рівні: функиіональне ядро, структурно-функиіональна надбудова та розширений функціонал. Наведена модель $\epsilon$ більш прийнятною для аналізу технологічно складних промислових товарів та інноваційних наукоємних товарів, оскільки від наявності функиіонального ядра товару та можливості компанії його монополізувати залежить ї̈ конкурентоспроможність та стратегічна стабільність ринкового положення. Також наведені моделі можливо використовувати для аналізу бізнесу в контексті бізнес-моделей, серед яких актуальними є бізнес-модель CANVAS та бізнес-модель Зозульова О.В. Перша зосереджена на складових бізнесу, таких як ключові споживачів, джерела ресурсів та склад витрат, ключові партнери та цінності для споживача, ключові ресурси тощо. Аналіз структурно-функціональної моделі товару в межах даної бізнес-моделі дозволяє уточнити виробничі аспекти конкурентоспроможності за кількома складовими. Друга бізнес-модель побудована на основі ланцңюжка изінності М. Портера, та передбачає аналіз иляхів набуття конкурентоспроможності за рахунок виділення ключових бізнес-прочесів. Структурнофункиіональна модель товару є важливою складовою, щэо впливає на формування виробничих процесів, які є ключовими для промислового ринку.

В контексті використання структурно-функиіональної моделі розроблена форма для аналізу створення цінності для споживача за допомогою товару. Окремо розроблено матрицю для аналізу потенціалу стійкості бізнесу в залежності від того, чи є монополізованим перший рівень товару $і$ хто є його власником. Зосередженість структурно-функціональної моделі на технологічних аспектах дозволяє визначити потенціальні загрози бізнесу в залежності від того, кому належить право власності на ключові технологічні вузли та прочеси. Відповідно, бізнес є або захищеним, або таким, щуо масово тиражується та існує, поки є вільний обсяг ринкового попиту або же єнші, нетехнологічні, маркетингові переваги.

Ключові слова: конкурентоспроможність, модель товару, бізнес-модель, стрес-тест бізнес-моделі. 
The article is devoted to the analysis of internal relations between marketing models of goods and models of analysis of business competitiveness, in particular model of 5 forces $M$. Porter and business models. The classification of marketing product models with the indication of key components and general direction of product analysis for each model is given. A structural-functional model is developed, which, unlike the existing ones, focuses not on the value that the product provides to the consumer, but on its technological and functional basis. The model has three levels: a functional core, a structural-functional add-on and an advanced functional. The given model is more acceptable for the analysis of technologically complex industrial goods and innovative science-intensive goods, since the competitiveness of the market and the strategic stability of the market depend on the availability of the functional core of the product and the ability of the company to monopolize it. Also, these models may be used for business analysis in the context of business models, among which the business model CANVAS and the O.V. Zozul'ov's business model. The first focuses on business constituents such as key consumers, resource sources and cost structure, key partners and values for the consumer, key resources, and more. The analysis of the structural and functional model of a product within the framework of this business model allows us to clarify the industrial aspects of competitiveness in several constituents. The second business model is based on Porter's value chain, and provides an analysis of ways to gain competitiveness through the allocation of key business processes. The structural and functional model of the product is an important component that influences the formation of production processes that are key to the industrial market.

In the context of the use of a structural-functional model, a form is developed for analysing the creation of value for the consumer with the help of a product. A matrix for analysing the business sustainability potential has been developed separately, depending on whether the first level of the product is monopolized and who owns it. The concentration of the structural-functional model on technological aspects allows us to determine the potential threats to business, depending on who owns the ownership of key technological units and processes. Accordingly, the business is either protected, or so massively replicated and existing, while there is a free market demand or there are other nontechnological, marketing benefits.

Keywords: competitiveness, goods model, business model, stress-test of business model.

Вступ. Конкурентоспроможність товару $є$ однією 3 наріжних складових конкурентоспроможності підприємства, успішності функціонування його бізнесмоделі. Не піддаючи сумніву важливість інших елементів комплексу маркетингу істина полягає в тому, що споживач ринку віддає власні кошти купуючи товар, що й формує основу фінансового успіху підприємства-виробника. Це обумовлює важливість аналізу теоретичних аспектів товару як ключової маркетингової категорії, зокрема маркетингових моделей товару.

Питання маркетингових моделей товару підіймалися у працях таких провідних вітчизняних та закордонних вчених, як Котлера Ф., Голубкова Є. П., Кардаша В. Я., Барейра П., Левітта Т., Благоєва В. та ін. Авторами цієї стаття також була запропонована модель, яка відображає технологічний аспект формування та концепції товару та аналізу його конкурентоспроможності на цій теоретичній основі. Детальний аналіз наведених моделей наведено авторами у [1].

Віддаючи належне вкладу цих авторів 3 точки зору практичної діяльності підприємства виникає потреба в аналізі існуючих моделей в контексті захищеності його конкурентних позицій. 3 цією метою для аналізу та групування маркетингових моделей товару було обрано модель п’яти сил, що визначають стан конкуренції в галузі М. Портера (рис.1). 


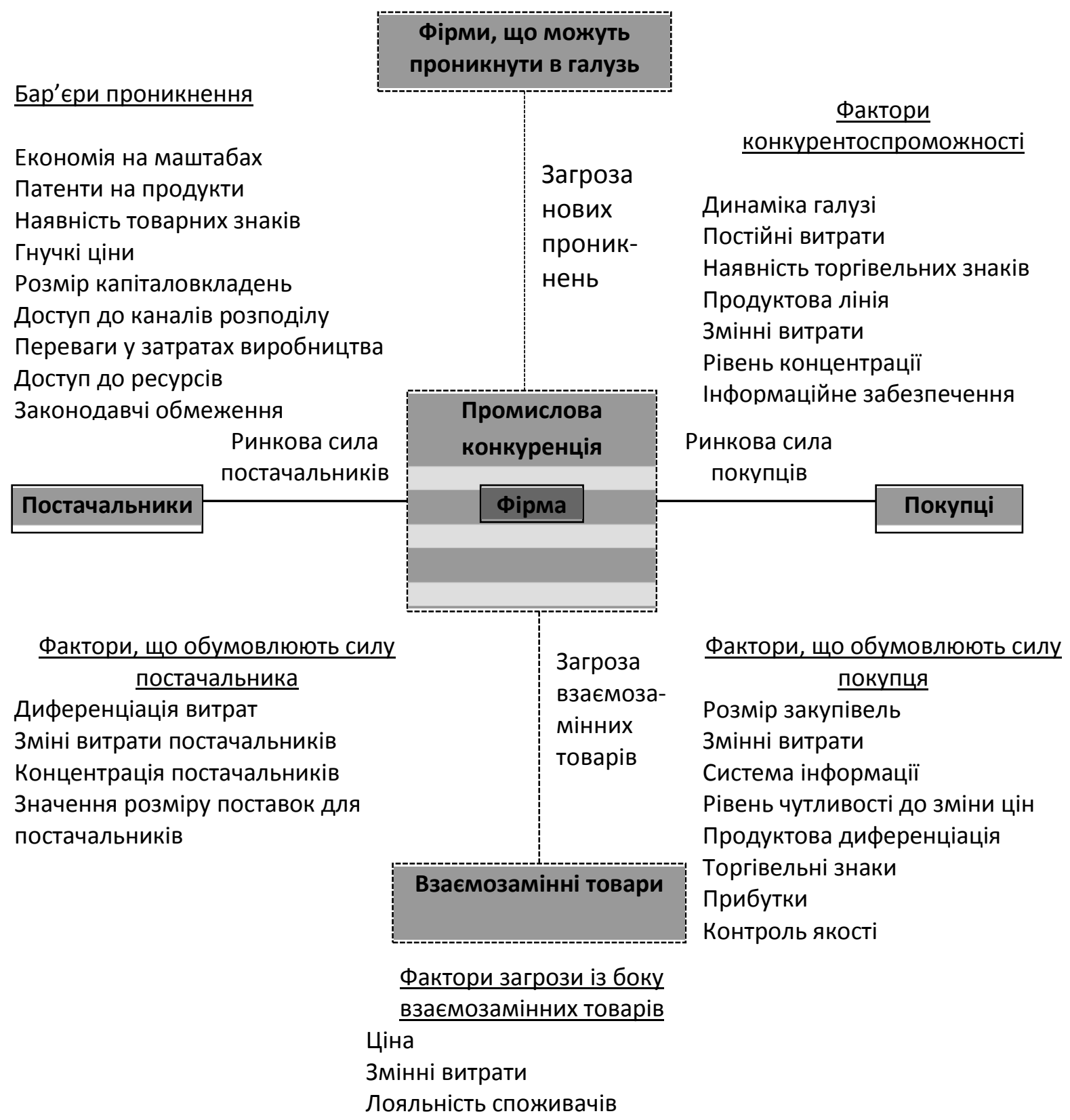

Рисунок 1 - Модель аналізу конкуренції на ринку М. Портера [2]

В межах моделі визначається специфіка конкурентної структури ринку, загрози з боку п'яти ринкових сил, що впливають на ринкову силу підприємства. Відповідно, в результаті аналізу моделі можна визначити вимоги до складових конкурентоспроможності гравців ринку. Такі вимоги також опосередковано будуть стосуватись товару, його моделі. Тому стає актуальним питання аналізу існуючих моделей товару в контексті аналізу конкурентоспроможності підприємства по відношенню до ключових ринкових сил, що визначають його конкурентоспроможність та впливають на успішність його бізнес-моделі.

Постановка завдання. Метою роботи $є$ формування маркетингової моделі товару як основи аналізу бізнес-моделі компанії.

Методологія. Теоретико-методологічною основою проведеного дослідження стали загальнонаукові методи наукового пізнання: монографічний, теоретичного узагальнення, систематизації, аналізу та синтезу. 
Результати дослідження. Аналіз існуючих на сьогодні основних маркетингових моделей товару дозволив класифікувати їх за ознаками, наведеними у таблиці 1.

Таблиця 1- Підходи до побудови моделей товару на маркетингових засадах [авторська розробка]

\begin{tabular}{|c|c|c|c|c|}
\hline № & $\begin{array}{l}\text { Підходи } \\
\text { побудови } \\
\text { моделей }\end{array}$ & Предмет дослідження & Зміст моделі & $\begin{array}{c}\text { Акцент } \\
\text { відносно } \\
\text { моделі М. } \\
\text { Портера п'яти } \\
\text { сил }\end{array}$ \\
\hline 1 & $\begin{array}{l}\text { Структурно- } \\
\text { статичний } \\
\text { Котлер, } \\
\text { Благоєв) [3; 4] }\end{array}$ & $\begin{array}{l}\text { Структура товару, як } \\
\text { мультиатрибутивної } \\
\text { цілісності }\end{array}$ & 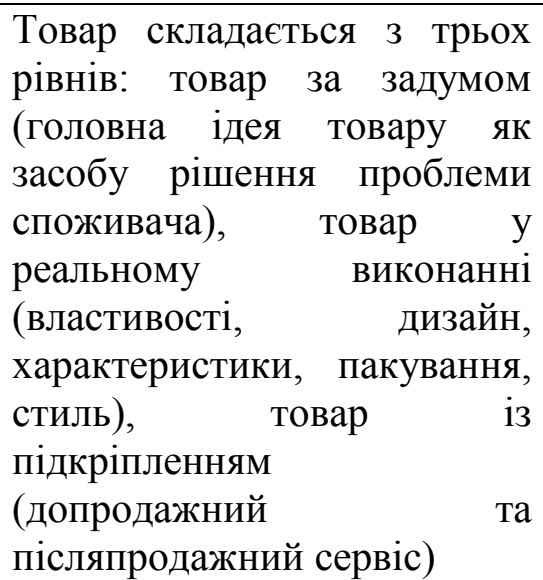 & Споживачі \\
\hline 2 & $\begin{array}{l}\text { Структурно- } \\
\text { динамічний } \quad \text { (Т. } \\
\text { Левітт) [3] }\end{array}$ & $\begin{array}{l}\text { Динаміка сприйняття } \\
\text { та формування образу } \\
\text { товару споживачем } \\
\text { (очікування та вимоги } \\
\text { до товару, образ } \\
\text { «ідеального товару») }\end{array}$ & 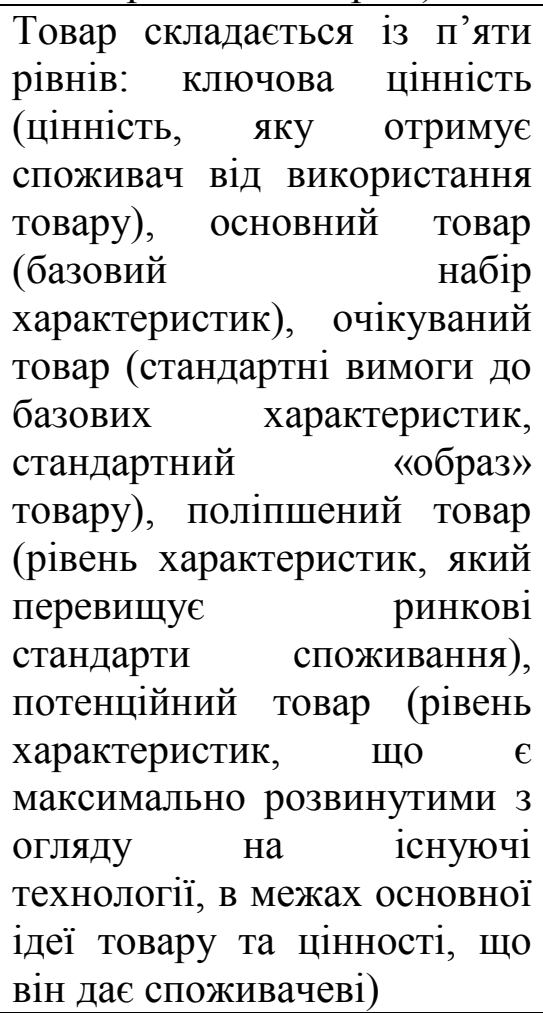 & Споживачі \\
\hline 3 & $\begin{array}{l}\text { Перцепційний } \\
\text { (Ж-Ж. Ламбен, } \\
\text { М. Фішбейн, П. } \\
\text { Діксон, Н. Кано) } \\
\text { [5, с. 208-209]. }\end{array}$ & $\begin{array}{l}\text { Сприйняття товару на } \\
\text { основі аналізу його } \\
\text { атрибутів }\end{array}$ & $\begin{array}{l}\text { Toвар як } \\
\text { корисностей: } \\
\text { «ядерна» послуга (цінність) } \\
\text { та дозова } \\
\text { цінності, корисності чи } \\
\text { послуги, що їх реалізують. } \\
\text { Водночас, в межах моделі } \\
\text { виділяються } \\
\text { товару, що атрибути } \\
\text { означені цінності }\end{array}$ & Споживачі \\
\hline
\end{tabular}




\begin{tabular}{|c|c|c|c|c|}
\hline 4 & $\begin{array}{l}\text { Ресурсно- } \\
\text { споживчий } \\
\text { (П. Барейра (для } \\
\text { інноваційних } \\
\text { товарів) [6; } 7, \text { с. } \\
\text { 495-497] }\end{array}$ & $\begin{array}{llr}\text { Ресурси, що } & \text { потрібні } \\
\text { для } & \text { задоволення } \\
\text { потреби } & \text { в } & \text { процесі } \\
\text { інновації } & & \end{array}$ & 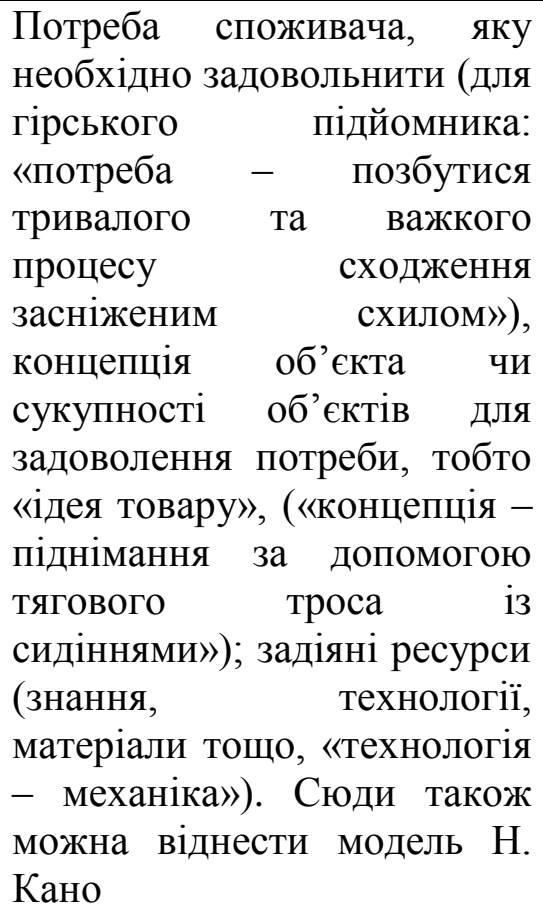 & Споживачі \\
\hline 5 & $\begin{array}{l}\text { Споживчо- } \\
\text { технологічний } \\
\text { (Зозульов О.В., } \\
\text { Царьова Т.О.) }\end{array}$ & $\begin{array}{lr}\text { Аналіз } & \text { технології } \\
\text { задоволення } \\
\text { споживачів }\end{array}$ & $\begin{array}{l}\text { Товар складається } 3 \text { трьох } \\
\text { рівнів: перший }- \text { принцип } \\
\text { задоволення } \\
\text { другий - спосібеби, реалізації } \\
\text { принципу як сукупність } \\
\text { послідовних процесів, третій } \\
\text { - фізична реалізація способу }\end{array}$ & Споживачі \\
\hline 6 & $\begin{array}{l}\text { Функціонально- } \\
\text { структурний } \\
\text { (Зозульов О.В., } \\
\text { Царьова Т.О.) }\end{array}$ & 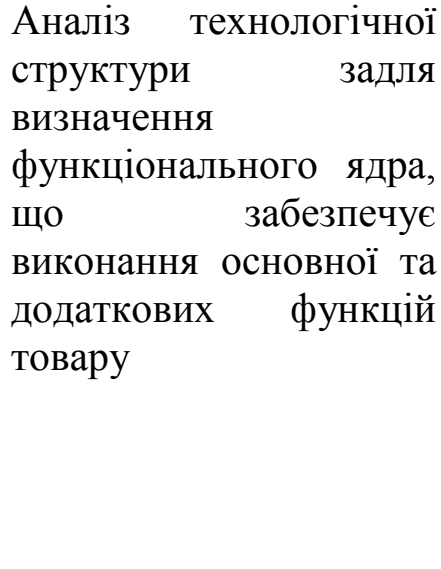 & $\begin{array}{l}\text { Tовар представлено трьома } \\
\text { рівнями: функціональне } \\
\text { ядро (функціональний вузол } \\
\text { чи блок, що забезпечує } \\
\text { виконання основної функції } \\
\text { товару), } \\
\text { функціональна надбудова як } \\
\text { сукупність базових функцій, } \\
\text { розширений фу функціонал } \\
\text { (технічні рішення, що } \\
\text { уможливлюють додаткові } \\
\text { сервіси та властивості) }\end{array}$ & $\begin{array}{c}\text { Споживачі та } \\
\text { постачальники }\end{array}$ \\
\hline
\end{tabular}

3 наведеного у таблиці 1 видно, що розроблені на сьогодні маркетингові моделі концепції товару (моделі 1-5) зосереджені на аналізі товару споживачем та не беруть до уваги взаємозв'язок із іншими ринковими силами, що визначають конкурентоспроможність компанії. Наведені моделі дають можливість аналізувати конкурентоспроможність товару в контексті визначених характеристик. Проте слід зауважити, що наведені моделі більше орієнтовані на аналіз простих товарів, для споживчого ринку, і переважно зосереджені на цінності споживача. Однак складні товари промислового призначення, особливо, товари наукоємні, що створено поєднанням кількох технологій, є більш прозорі 3 точки зору визначення ключової потреби, задля якої вони створені (часто це відображено у їхній назві, або у назві товарної категорії), i, водночас, технологічно є складними. I саме це часто $є$ основою конкурентоспроможності товару. Отже, структурно-функціональний підхід зосереджено саме на аналізі 
технологічної структури товару як основи його функціональності товару та на визначенні його функціонального ядра (рис. 2).

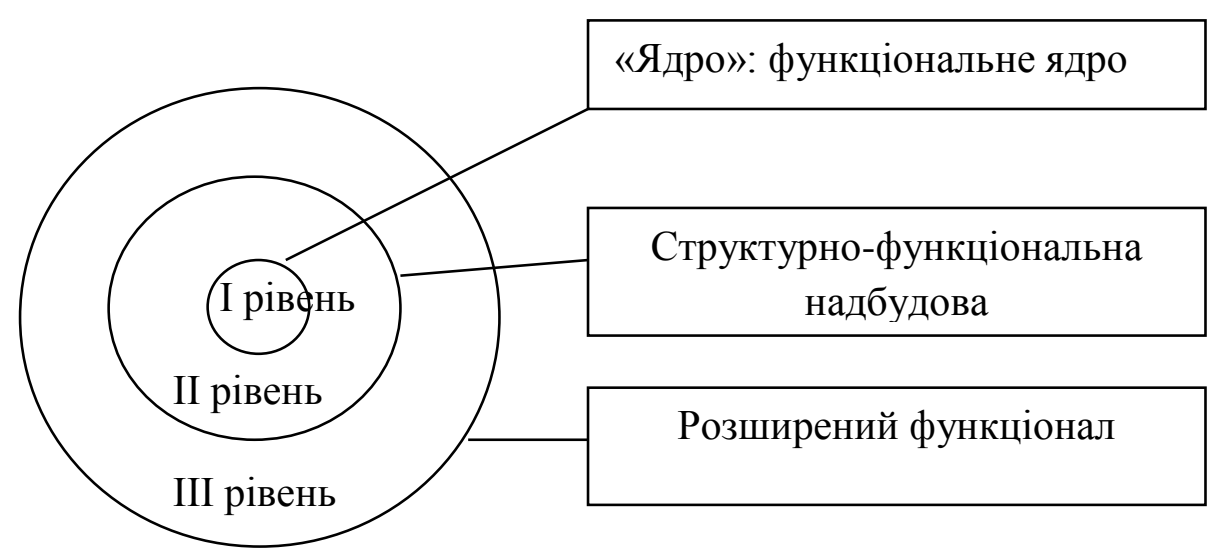

Рисунок 2 - Функціонально-структурна модель товару [авторська розробка]

Наддамо характеристику основних складових цієї моделі:

- Функціональне ядро - складова товару (вузол, блок, програмне чи програмноапаратне забезпечення тощо), що забезпечують реалізацію виконання основних функції товару. Функціонування ядра забезпечує реалізацію функцій другого рівня. Товар може мати декілька функціональних ядр або взагалі не мати жодного. Наприклад, програмне забезпечення для послуги ринкової аналітики або контролери для управляючого пристрою.

- Структурно-функціональна надбудова - сукупність функцій, які забезпечуються за рахунок структурних складових, функціонування яких забезпечується ядром та створює базову цінність для споживача (базова пропозиція). Наприклад, отримання проміжних часткових даних та інтеграція розрізнених результатів ринкового аналізу у цілісну картину, що синтетично зображує ринкову ситуацію.

- Розиирений функціонал - технічні рішення, що забезпечують створення додаткових сервісів та властивостей, що розширюють функціональні можливості товару. Наприклад, програмно-апаратні рішення, що забезпечують інтеграцію CRM-системи у програмне забезпечення по управлінню маркетингом на підприємстві. Або можливість отримання прогнозів розвитку ринкової ситуації на основі додаткового моделювання поведінки ринкових факторів у випадку ПО для послуги ринкової аналітики.

3 метою аналізу ролі наведеної вище моделі для поглиблення аналізу маркетингових бізнес-моделей підприємств ведемо декілька найбільш релевантних.

Однією з найбільш поширених є модель CANVAS (Business model canvas), авторами якої є Олександр Остервальдер і Ів Пинье [8] (рис. 3). Бізнес-модель в першу чергу призначена для аналізу діючих бізнесів компанії 3 метою знаходження слабких місць або нових точок зростання. 


\begin{tabular}{|c|c|c|c|c|c|}
\hline \multirow[t]{2}{*}{$\begin{array}{l}\text { Ключові } \\
\text { Партнери } \\
\text { Хто наші } \\
\text { партнери? } \\
\text { Хто наші } \\
\text { постачальники? } \\
\text { Які ключові } \\
\text { ресурси ми від } \\
\text { них отримуемо? } \\
\text { що цінного вони } \\
\text { для нас } \\
\text { роблять? }\end{array}$} & $\begin{array}{l}\text { Ключові дії. План- } \\
\text { графік діяльності. } \\
\text { Для каналів збуту? Для } \\
\text { налагоження стосунків з } \\
\text { споживачами? Для отримання } \\
\text { та обліку коштів? } \\
\text { що потрібно зробити,щоб діяв } \\
\text { проект? }\end{array}$ & \multirow{2}{*}{\multicolumn{2}{|c|}{$\begin{array}{l}\text { Головна ідея, } \\
\text { цінність } \\
\text { що пропонуете? Головна } \\
\text { ідея, опис. } \\
\text { Які проблеми споживачів } \\
\text { вирішуемо? } \\
\text { що цінного в нашій } \\
\text { пропозиції? } \\
\text { Які послуги ми можемо } \\
\text { запропонввати кожному з } \\
\text { сегментів споживачів? }\end{array}$}} & $\begin{array}{l}\text { Взаємодія } 3 \\
\text { споживачами } \\
\text { Які у нас стосунки з } \\
\text { кліентом? } \\
\text { Як вони інтегровані? } \\
\text { Наскільки дорогі для нас? }\end{array}$ & \multirow[t]{2}{*}{$\begin{array}{l}\text { Сегменти } \\
\text { СпожИвачів } \\
\text { Для кого ми працюемо? } \\
\text { Який споживач для нас } \\
\text { найважливіший? }\end{array}$} \\
\hline & $\begin{array}{l}\text { Ключові ресурси } \\
\text { Які ключові ресурси нам } \\
\text { потрібні для реалізації } \\
\text { проекту? } \\
\text { Люди? Час? Гроші? }\end{array}$ & & & $\begin{array}{l}\text { Канали } \\
\text { Через які канали кліенти } \\
\text { хочуть отримати наші } \\
\text { ценності? } \\
\text { Через які канали вони ї } \\
\text { отримююь зараз? } \\
\text { Які найбільш ефективні? }\end{array}$ & \\
\hline \multicolumn{3}{|c|}{ Структура витрат } & \multirow{2}{*}{\multicolumn{3}{|c|}{$\begin{array}{l}\text { Отримання коштів. Фандрейзинг } \\
\text { За що наші грантодавці, спонсори, меценати готові платити? } \\
\text { За що вони платять зараз? Як вони платять? } \\
\text { Яка доля кожного з потоків, в загальній сумі доходу? }\end{array}$}} \\
\hline \multicolumn{3}{|c|}{$\begin{array}{l}\text { Які найважливіші витрати, пов'язані э бізнес моделлю? } \\
\text { Які ключові ресурси є найдорожчими? } \\
\text { Які основні діі є найдорожчими? }\end{array}$} & & & \\
\hline
\end{tabular}

Рисунок 3 - Бізнес-модель Canvas [8]

Іншою моделлю, запропонованою для аналізу бізнесу, $\epsilon$ модель О.В Зозульова (рис. 4), яка зосереджується на визначенні ядра компетенції компанії ключових бізнес-процесів та функцій, що визначають конкурентоспроможність компанії на ринку.

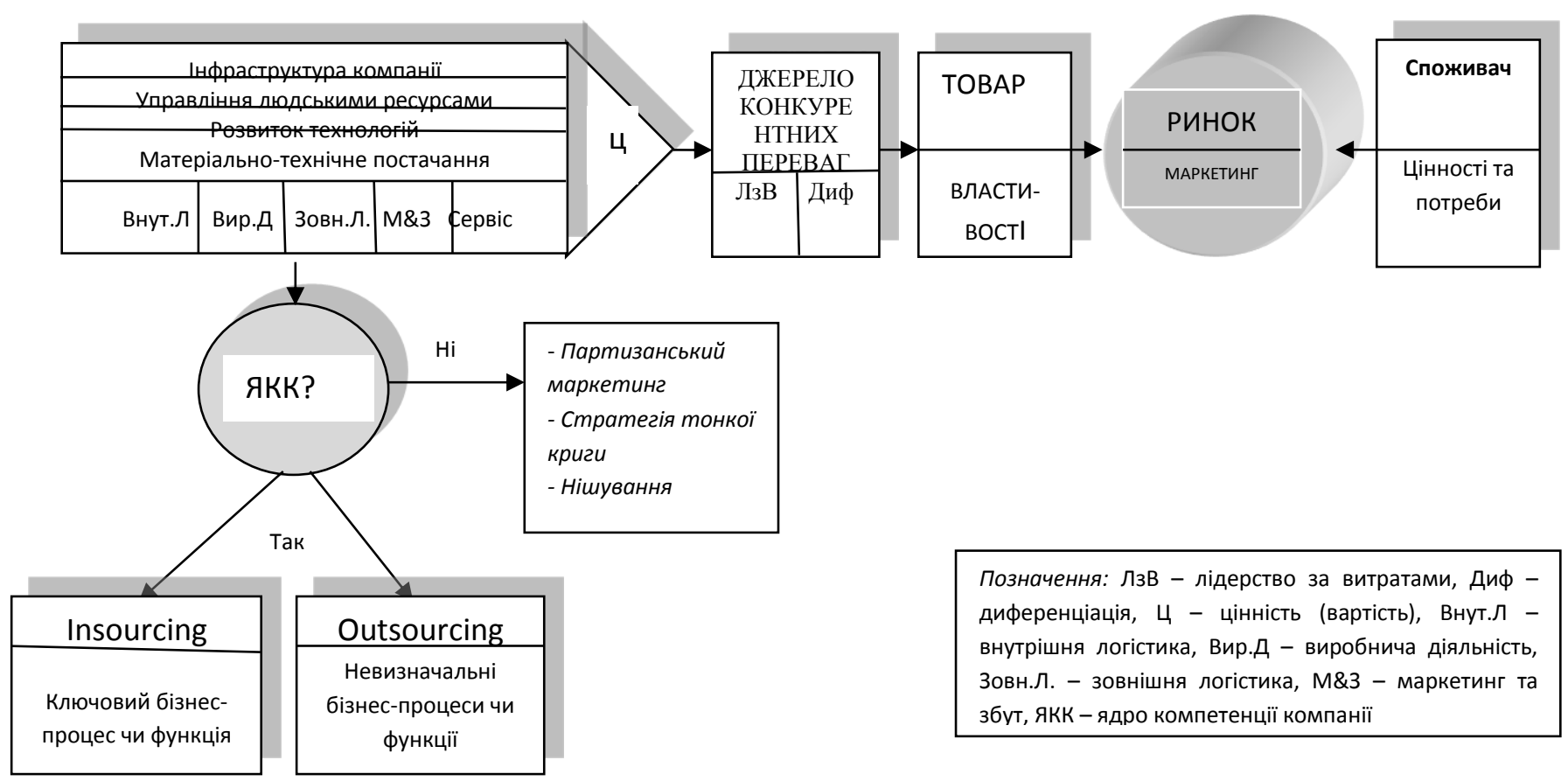

Рисунок 4 - Модель організації бізнесу на основі ланцюга створення вартості М. Портера [9]

Як видно з наведених рисунків дані моделі роблять наголос на тому, що конкурентоспроможність товару на ринку обумовлена здатністю компанії так 
«підтягнути» до ринкових вимог власні внутрішні процеси та зв'язки із контрагентами, щоб забезпечити створення цінності для споживача. В цьому контексті формування успішної бізнес-моделі неможливо без запропонованої моделі товару, оскільки вона закцентована на функціонально-структурному аспекті формування концепції товару як ключового елементі будь-якої бізнесмоделі, що дозволяє урахувати зв'язок «постачальник»-«виробник»-«споживач». Вона дозволяє прорахувати, яким чином буде технологічно створюватися функціонал товару, який формує цінність для споживача, та як це вливає на залежність компанії від постачальників. Для аналізу створення цінності для споживача товаром з використанням запропонованої функціонально-структурної моделі можна користуватися формою, наведеною у таблиці 2.

Таблиця 2 - Форма для аналізу створення цінності для споживача за допомогою товару з використанням функціонально-структурної моделі

\begin{tabular}{|c|c|c|c|}
\hline Рівень товару & $\begin{array}{l}\text { Функції, що } \\
\text { виконуються }\end{array}$ & $\begin{array}{c}\text { Структурні елементи, } \\
\text { що забезпечують їх } \\
\text { реалізацію }\end{array}$ & $\begin{array}{l}\text { Цінності, що створюються для } \\
\text { споживача }\end{array}$ \\
\hline $\begin{array}{c}\text { Функціональне } \\
\text { ядро }\end{array}$ & & & \\
\hline $\begin{array}{c}\text { Структурно- } \\
\text { функціональна } \\
\text { надбудова } \\
\end{array}$ & & & \\
\hline $\begin{array}{c}\text { Розширений } \\
\text { функціонал }\end{array}$ & & & \\
\hline
\end{tabular}

Розроблена модель товару формує підгрунтя для стрес-тестування бізнесмоделі компанії. Стрес-тести сьогодні використовуються національними (центральними ) банками для аналізу стійкості банку. Такий підхід доцільно розширити й для аналізу інших бізнесів.

Під стрес-тестуванням бізнес-моделі компанії будемо розуміти таку форму тестування, яка передбачає визначення стійкості функціонування підприємства, його здатності до отримання прибутку 3 використанням сформованої бізнес-моделі за умов зміни маркетингового середовища.

Стрес-тестування передбачає проведення кількісного та якісного аналізів. Сформована модель товару дозволяє провести базовий стрес-аналіз бізнес-моделі, зокрема на предмет здатності створювати та утримувати необхідну для споживача цінність (рис. 5). 


\begin{tabular}{|c|c|c|c|}
\hline \multirow[t]{2}{*}{$\begin{array}{l}\text { Чи є користувач } \\
\text { «ядра» його } \\
\text { власником? }\end{array}$} & Так & $\begin{array}{c}\text { Бізнес є надійно захищеним } \\
\text { від копіювання }\end{array}$ & $\begin{array}{c}\text { Ринок сповнено бізнесами- } \\
\text { копіями, відносно низький } \\
\text { рівень } \\
\text { конкурентоспроможності, треба } \\
\text { удосконалювати бізнес-модель. }\end{array}$ \\
\hline & $\mathrm{Hi}$ & $\begin{array}{c}\text { Бізнес-модель може бути } \\
\text { зруйнованою через вилучення } \\
\text { «ядра» його власником або } \\
\text { передачу прав користування ним } \\
\text { іншим ринковим суб'єктам }\end{array}$ & $\begin{array}{c}\text { Низький рівень } \\
\text { конкурентоспроможності, } \\
\text { бізнес можна скопіювати у } \\
\text { будь-який час }\end{array}$ \\
\hline
\end{tabular}

Так $\mathrm{Hi}$

Чи монополізовано «ядро»?

Рисунок 5 - Типи стійкості бізнес-моделі компанії на основі аналізу функціонально-структурної моделі товару[авторська розробка]

Наведена матриця дозволяє оцінити стійкість компанії у контексті іiі здатності до монополізації основного функціонального «ключа» продукту. Проте запропонована функціонально-структурна модель може бути використана для аналізу в межах кожної складової моделі CANVAS. Моделювання ринкових змін за кожною складовою цієї бізнес-моделі із використанням структурнофункціональної моделі товару і $\epsilon$ основою для окремого випадку стрестестування.

Висновки. Стрес-аналіз бізнесу, по суті, моделювання його конкурентоспроможності, вимагає застосування широкого спектру інструментів, які дозволять оцінити стійкість та переваги різних аспектів функціонування компанії. Функціонально-структурна модель товару може стати у нагоді за випадку аналізу конкурентоспроможності, пов'язаної із виробленням та використанням технічно складного промислового товару. Подальшим напрямом досліджень є застосування функціонально-структурної моделі для формування товарної політики, а саме її інноваційної складової в контексті аналізу життєвого циклу трьох рівнів моделі.

\section{Література:}

1. Зозульов О.В., Царьова Т.О. Процесно-технологічний підхід до формування маркетингової моделі товару. Економічний вісник Національного технічного університету Украйни "КПГ". - К.: НТУУ «КПІ» ВПІ ВПК «Політехніка» - 2016. - №13. - С. 369-376.

2. Портер М. Стратегія конкуренції. Методика аналізу галузей і діяльності конкурентів (Переклад з англ. А Олійника та Р. Скіпальського). К.: Основи, 1997. - 390 с.

3. Котлер Ф. Маркетинговий менеджмент : підручник / Ф. Котлер, К.Л. Келлер, А.Ф. Павленко та ін. - К.: Видавництво Хімджест, 2008. - 720 c.

4. Благоев В. Маркетинг в определениях и примерах / В. Благоев; пер. с болг., науч. ред. и автор предисл. А. М. Немчин. - СПб.: «Два-Три», 1993. - 377 с. 
5. Божук С. Маркетинг : учебник для ВУЗов / С. Божук, Л. Ковалик, Т. Маслова, Н. Розова, Т. Тэор. - Спб.: Питер, 2012. - 448 с.

6. Noriaki K., Seraku N., Takahashi F., Sh. Tsuji. Attractive quality and must-be quality. Journal of the Japanese Society for Quality Control (in Japanese) - 1984. - № 14 (2). - p. 147-156.

7. Ламбен Жан-Жак. Менеджмент, ориентированный на рынок / Жан-Жак Ламбен ; перев. с англ. под ред. В. Б. Колчанова. - СПб. : Питер, 2004. - 800 с.

8. Osterwalder A., Pigneur Y. The Business Model Generation. - USA, Wiley\&sons, 2010. - 278 p.

9. Зозульов О.В. Формування концепції ведення бізнесу на маркетингових засадах: сьогодення та майбутнє. Маркетинг в Україні. - 2017. - № 5-6 - С. 64-72. 